\title{
Relationships in Anglo-Saxon, Balkan Ballads and Epic Songs
}

\author{
Danela Bala- Kraja \\ M.sc. , Phd. Cand, Lecturer, University of Shkodër Albania \\ Lagja: Kongresi i Permetit, Rruga: Oso Kuka, P: 736, Shkodër, Albania
}

\begin{abstract}
This article aims to point out the diverse relationships that are to be found in Anglo- Saxon and Balkan ballads and epic songs. There were different kinds of relationships such as human and non- human relationships. The most important relationships were those familial ones because family stands as the most important part of the society. In many cases relationships cannot stand and cannot be treated alone because they are interconnected with other ones. In that time the mentality and behaviour were not the same with the ones we have nowadays as there were restrictions and unwritten laws and people were following them but as always happens they were not always going to be strictly followed and that generated conflicts and reactions. There are made different researches and parallels to understand how different peoples may react in different relationships. They had a real great and powerful significance and value on people and their connections and were an important factor on determining people's behaviour, on stabilizing the tranquillity and peace of their families, societies and countries.
\end{abstract}

Keywords: ballads, relationships, parents, daughters, epic songs

Ballads and epic songs were written a long time ago and apart their undeniable and worthy values they have as the first pieces of written literature, they are also part of the written evidence to record and transmit to other generations the large range of diverse relationships and sub relations they have which at that time were quite different from the ones we have nowadays. So, taking into consideration the time evolution today people are more open minded being aware that they are free to talk, communicate, act and express their opinions, attitudes, emotions and feelings without being afraid or threatened that something bad will happen to them as it did not use to be so in the Middle Age period because people were strictly following the codes and rules.

Throughout the span of the large number of ballads, epic lays and frontier warriors songs there are displayed a wide range and a different scale of relationships that are also interconnected with one another beginning with human and non- human relationships If there are mentioned human relationships we may go on dealing more specifically with the most basic ones which have to do with familial ones: wife- husband, father-son, father- daughter, mother- daughter, mother- son, brothersister, brother- brother, sister- sister and going on with other ones such as social ones including one of great importance best friends, political, love, mythological creatures (non-human relationships), open and close ones and so on. Those stand also as the basis and the core of many ballads and epics plot which show how diversified characters and consequently unknown reactions people may have in certain situations.

First of all as it is known human relationships have always been complicated throughout all the times and if it is to be given a category about the most important ones familial relationships are the first that come in rank. The fact of being a parent has been difficult at that time and even nowadays there is no doubt that it is one out of the hardest responsibilities the spouses have in managing the family. Women were considered and seen by the society as the weak sex, they were prejudiced and if there are illustrations to be underlined there would be those unusual ones when they were not playing their natural role not being loyal and faithful to their husbands and fiancés and as a result there would be reactions and once in a while having bad outcomes. Although parents were older in age and were supposed to be protecting their children during all their life, sacrifice everything for them, they were also supposed to be more mature and their decisions were to maintain family bonds strong and keep it united, they were not always the right ones because sometimes they were obliged 
(by the unwritten laws) to make tough decisions, they reacted in a such a strong way going up to slaying their daughters such as 'The cruel brother' where the brothers stabs her own sister in her wedding. There were especially girls and women (sometimes portrayed or implicated as the most delicate and fragile characters) who were mostly affected because they were more dependent on their family (parents or brothers) and they had to be obedient and to accept their destiny as well even about important life decisions such as to choose the appropriate husband or even to decide if they had the right to live.

As it is above mentioned it was a different time which also affected people who used to have sometimes a strange behaviour, too. It is a period when their parents in general were very authoritarian and at the same time they were not so collaborative because they did not accept the fact and likewise allow that their daughters could be able to fall in love and be free to choose themselves their husbands or what was considered more to have premarital sexual contacts which was regarded as a taboo. They were in control of their daughters' lives and were able to decide about them. But, although there were severe and hard limitations, life continued and as it always happens there are exceptions to the rules and not always those unwritten laws were strictly followed and as it occurs when there are severe and strict restrictions there are also breaking the rules fragments. So there are not rare the occurrences when the daughters were pregnant in premarital relationships (more frequently found in Anglo- Saxon ballads) and as a result in many cases they were obliged to abandon their family and leave with their beloveds but such an action was not without consequences. These examples are more frequent in Anglo-Saxon ballads but even in Albanian ones it is found the brother who gives the decision to accept the marriage of his sister to an unknown person living far away like in 'Constantin and Doruntine'. In Albanian ballads the role of the brother is mainly protective. His character is presented as the strong one who has gone to fight since when he was small but it is also intertwined with other social qualities where the most important ones are honour, faith, courage and bravery in other words he was a hero. What is an important feature of the portrait is that they keep their given word of honour, oath, and because of the that promise even after death they are not quiet and they get out of the grave only to fulfil a duty he left hanging that was to bring his sister home to meet her mother. An important social phenomena that is incest never happens in Albanian ballads or if it is going to happen there is always something or someone that stops it from the execution such as a mythological character for instance a bird speaking or a sign that makes people stop from the act while in Anglo- Saxon ones unfortunately in some instances that happens such as 'The sheath and knife' and in many cases the siblings recognize one-another too late which brings tragic results and they find solution only by giving an end to their lives through suiciding both brother and sister.

In sister- brother relationship in many instances their connections and their bonds are really impressive and inspiring because the sister in many cases is self-sacrificing herself first of all as it is mentioned in many ballads by not living her life, not running after dreams and not accepting to get married but deciding to stay near her languished brother helping him recover, feeding and trying to treat his wound and later when he worsens like a real heroine she is ready, instead of him, to go and save her country and honour, too as in the ballad 'Gjergj Elez Alia'. So when the wounded brother is suffering in bed with nine wounds received in battles, without taking into consideration the fact that she is sacrificing her life for her brother she laments the fact that she may be will have the turn to go to baloz.

What of the hero, Gjergj Alia?

He'd sent his greetings to the baloz,

To meet him early at the war grounds.

I've no maiden for you baloz,

My sheep have not been fattened for you,

I've but one sister, not to give you,

Who else would bind my injured body?1

\footnotetext{
${ }^{1}$ Elsie R., Mathie- Heck J. (2004) Songs of the frontier warriors. Wauconda, Illinois: Bolchazy- Carducci Publishers
} 
So brothers are concerned about their sisters and they think it is their duty to protect their family and country and so they want to solve and do everything themselves and do not accept the fact to let the burdens to their sisters.

The siblings' connection attracts to study their reactions and normal or abnormal behaviour (there must be something really strong to make people write about). They are brothers, they are best friends but notwithstanding they are there examples seeing them as the worst enemies. They fight together for one main cause to keep their country free from enemies and occupiers but there are cases when they fight against one- another, in some instances because they do not now they are brothers because due to circumstances they were grown up separately. They vow to do something together but there is one that breaks the promise. In the end they finish by reconciling and feeling bad. Even sisters in Anglo- Saxon ballads are presented in some occasions as jealous of one of them and they arrive up to the case of wishing and planning their sister's murder.

So, however as it is pointed out the women relationships must not be seen only at one side because they are not always so weak on the contrary their influence on their decisions was very crucial because there are occasions that due to familial relationship husband- wife the whole community could profit as it is the case of the immured woman Rozafa. She accepted to be immured, allow and quit everything especially her maternal duty and the circumstances made her let her own baby orphan as it was her husband even he obliged by the fact of finishing the castle which required that sacrifice and only if that immurement was done the castle could be built and people would benefit from it. They were presented and also depicted as really responsible people not thoughtless ones because even afterlife they do not think to rest as they continue to think how to submit their motherhood duties. One of the few things Rozafa asked before she was immolated was to let part of her body out so that she could continue breastfeed her baby when it was hungry, watch and rock it when it was crying and needed to sleep. Today her bravery is still sung and her story is considered and mentioned as a legend. As it is known there are illustrations that they had a great importance and great impact especially playing the role of mothers, sisters and wives, fiancés, lovers because they could change the turn of the events and likewise the wheel of the history and were also the ones that held the responsibility for life continuation. Similarly in songs of the Serbian people it is 'The building of Skadar' which is a likewise version of Albanian Rozafa that shows the strength that women have.

$$
\begin{aligned}
& \text { 'Brother Rade, hear me out in God's name, } \\
& \text { and leave a space, a window for my eyes, } \\
& \text { so I can see, can look on my white hall, } \\
& \text { can see my son, when they bring him to me, } \\
& \text { and when he leaves, when they take him away.'1 }
\end{aligned}
$$

On the other hand in Albanian ballads and frontier warrior songs the father relationships are weakly mentioned so it is the mother that has the power to keep the family bonds strong and encourage her sons (they are presented through songs as are more powerful considered to fathers' role) either to continue to fight for something good (mainly for their boundaries) or impedes them when she sees something does not go well while in Serbian ballads fathers again are not so often mentioned but they are implied and their sons fight even for them and when they learn that something bad has happened to their fathers they become furious.

People used to live a simple life and their feelings were more open and their characters were less complicated so if they had something they were bolder to express it mostly through actions. When the word mother is mentioned the first idea that comes to everybody in mind is that she is everything for her own kid such as love, security, protection and tenderness and that something that they do really well indeed is their role is as in the case of the epic lay 'Beowulf' it is the mother that wants to protect her own creature even when he does not live and her pain is so big that she wants to revenge. She went to fight like a dragon even after his death and is ready to sacrifice everything even her own life only for her son. It is really interesting and impressive to read her reactions and her attitudes when she learns about her son's death and asks him back in her wailings. Similarly still in Albanian and Serbian mothers they have the same feelings for their children and this

\footnotetext{
${ }^{1}$ Karadzic, Vuk (1997) Songs of the Serbian people, University of Pittsburgh Press
} 
connection is highly expressed by their feelings, responsibility of keeping an eye always on their children, mourning and lamenting or their falling dead when they learn that their children died and vice versa.

The nine's mother prays long to her dear God

that He give her the eyes of an eagle

and the wide wings of the white- feathered swan,

that she might fly o'er Kosovo's flat field,

and might see there the nine Jugovićes ${ }^{1}$

However on the other hand there are examples of mothers abandoning and hurting their children because they want to follow their love. So they collaborate in hurting their own children by making plans of blinding and killing them, plans which in the beginning seem to function but in the end they recover themselves and their mothers are punished an example to be mentioned would be that of 'Jovan and the leader of the giants'.

Women apart men also had a substantial and really important part in the political system as young girls were married to regulate political and social system of two countries and usually the inborn part of the woman nature is that she loves peace and tranquillity she never wants to solve the possible problems by fight and war. So firstly their prior contribution was to calm down the people, to convey messages of peace and in some other instances to strengthen more their agreements.

Love was, is and will continue to be the feeling and the emotion of the first inspirations of poetry, songs, ballads, novels, tragedies, films, plays and so on. Even in Middle Age period that used to be the essential motif to regulate or break different relationships and it was used as a means through which people used to weaken other people and achieved what they intended. It is difficult to speak separately about different relationships because they cannot be treated apart as single and individualized ones. When a person has an inevitable feeling he reacts in a way which is may be in contradiction with a certain behaviour and later on also may regret. In search of love which sometimes is not responded by the other person people may be able to do things they would not normally do which would not even imagine. In many ballads that is the reason that unresponsive love worsens conditions and makes people feel bad.

God takes an important role as people do believe in him and they always address to him, they go to churches and pray for him. Albanian epic frontier warrior songs in the majority of the songs begin by referring to the Almighty God and also the Serbian songs mention that they would ${ }^{2}$ not dare to shed the blood in honour of the cross, and they usually end their songs by directing to God and even in the Anglo-Saxon epic lay 'Beowulf' people believe in him and the main character dedicates his victory not only to his strength and power but to God also.

'Look at Boško, the coward Jugović!

He did not dare to go to Kosovo

To shed his blood in honour of the Cross

And give his life for the faith of the Christians.'

${ }^{1}$ Karadzic, Vuk (1997) Songs of the Serbian people, University of Pittsburgh Press

${ }^{3}$ Karadzic, Vuk (1997) Songs of the Serbian people, University of Pittsburgh Press 
My time 'tis to go. May the Father Almighty

With His gracious favour for now preserve

Safe on your journey! I will at the sea

'Gainst hostile band keep guard at the coast. ${ }^{1}$

The main characters sometimes think that the weak point of their enemies is by offending them by breaking the rules of the other's side belief. In fact in many cases some traditions that are in mentioned in the songs are pagan ones.

The main characters were usually followed by thirty people that were ready to fight for their leaders that could be king, tsar, lord, or just simple people as Muj in Albanian epic songs and their relationships were primarily based on word of oath, bravery, and capacity of being able to fight. They were also faithful because when they learnt that something bad threatened either their country or their friends they did not think twice but went immediately to fight and put justice and they were brave enough to die without having regrets. The main problems that they were fighting for were ownership ones. They protected their land and boundary till the last moments of their lives but as it always happens there are cases that the main heroes are abandoned as it is the case of Beowulf that remained alone in his last battle accompanied only by one thane that stood near him and had to accomplish his last wills. The neighbourhood relationships between simple people as a matter of fact if they did have bad purposes were not bad ones. People beyond bad intentions could go from one country to another without having any obstacles.

The mythological characters had a great influence in creating and maintaining different kinds of relationships which in many cases had a high impact which could affect and change completely even the main characters' personality and life. So in the case of Muj, one of the main heroes in Albanian epic songs, he passes from the state of feeling a humiliated shepherd with no physical strength to that of a really powerful person and he changes completely that is due to the force that ora-s gave by giving him some drops of their milk. When the heroes fight as it is mentioned they must be accompanied and have their protectors awake because they fight with them, too. Then may have dual characters in the sense that they play the role of simple people and also heroes when it is needed. The oras, zanas, vilas had supernatural strength and people had to be careful with them, they must not annoy and enrage them because otherwise if they were enraged their reaction would be a bad one having bad consequences as they had the power to transform people into stones. Usually they are described as beautiful creatures such as the sirens and mermaids in Anglo- Saxon ballads and human people were attracted by them and vice versa. They had something like magic supernatural because they were the ones who predicted people about a misfortune which was going to happen and prepare them to take measures.

Even the nature had its relationship with people such as for example the sun, the moon, the birds, the stones, the trees, the horses and so on. People had their relationship with them believed in them and when they wanted to take a trip or do something they directed to them, they saw the moon and knew if it was the right time to take that adventure or not. One of the strongest relationships is that warrior- horse because that was a really powerful determinant in designating their victory and when their enemies wanted to take something valuable apart other important ones that was the horse. Even the saber and the dagger were important because they were really crucial in deciding if winning or not the battles or fightings and heroes direct to them as their best friends.

These were only some of the relationships taken from the diverse range of relationships and of course there are other ones not highlighted in this article but the above mentioned ones are some of them which had a real great and powerful significance and value on people and their connections and were an important factor on determining people's behaviours and reactions, on giving their contribution in stabilizing the tranquillity and peace of their families, societies and countries.

\section{BIBLIOGRAPHY}

[1] Child Fransis James, 'The Scottish and English popular songs', Boston: Little, Brown and company, 1857

\footnotetext{
${ }^{1}$ Garnet, James M. (1912)Beowulf, Ginn \& Company, Boston
} 
[2] De Roche Joseph 1988 The heath Introduction to poetry, Massachusetts/ Toronto D. C. Heath and Company, Lexington,

[3] Elsie, Robert and Mathie Janice: (2004): Songs of the Frontier Warriors, Wauconda, Illinois: Bolchazy Corducce Publishers.Inc

[4] Garnett, James M.,(1912)Beowulf Boston, Ginn \& Company

[5] Heaney, Seamus: (2000) A new verse Translation, Bilingual edition, New York, Farrar Straut and Giroux

[6] Karadzic, Vuk (1997) Songs of the Serbian people, University of Pittsburgh Press

[7] Palaj Bernardin, Kurti Donat, (2005), Eposi i kreshnikeve dhe balada, Tiranë, Plejad

[8] Quiller-Couch Arthur 2014 The Oxford book of ballads, Oxford at the Clarendon Press

[9] Zoto, Vladimir (2006) Balada shqiptare, Tiranë, Dasara 